\title{
Ontogeny of Cell Type-Specific Enzyme Reactivities in Kidney Collecting Ducts
}

\author{
HARRY HOLTHÖFER
}

Department of Bacteriology and Immunology, University of Helsinki, Helsinki, Finland

\begin{abstract}
Highly specific antibodies against vital enzymes of the collecting ducts were used to study the appearance of cell type specific enzyme profiles in developing rat kidneys. (Na+K)-ATPase, the abundant enzyme of principal cells, could be detected early in utero in most collecting duct cells. However, the characteristic basolateral polarization of this enzyme did not appear until the first hours after birth. After this, the relative amount of $(\mathrm{Na}+\mathrm{K})$-ATPase immunoreactive cells along collecting ducts decreased steadily, to reach the amount found in adult rat kidneys by the 30 th postnatal day. Carbonic anhydrase immunoreactivity characteristic for intercalated cells was not detectable in fetal kidneys, but appeared soon after birth, with steadily increasing numbers of cells that were positive. Interestingly, immunoreactive band 3 glycoprotein (anion channel protein of erythrocytes) did not appear until the 5th day of life, with only a slowly increasing number of cells positive for this probe. These results, showing the sequential appearance of cell type-specific enzyme reactivities along collecting ducts, likely reflect a similar pattern of functional development of the respective main cell types. These results may provide an explanation for physiologic neonatal acidosis, as the enzyme profile associated with proton secretion was seen to appear slowly during the first weeks of life in a distinct manner. (Pediatr Res 22: 504-508, 1987)
\end{abstract}

\section{Abbreviations}

CA II, carbonic anhydrase

SDS-PAGE, sodium dodecyl sulfate polyacrylamide gel electrophoresis

ABC, avidin-biotin-horseradish peroxidase

DAB, diamino benzidine

The so-called principal cells of the renal collecting ducts have been shown to be vitally involved in the final regulation of urinary electrolyte composition (1-3), whereas a separate population of epithelial cells, the mitochondria-rich (intercalated) cells at this site, preferentially regulate renal acid-secretion (1, 4-6). Recent studies have shown that in rat kidneys, the vital transport enzymes involved in these important functions of collecting ducts, $(\mathrm{Na}+\mathrm{K})$-ATPase $(7,8)$ and carbonic anhydrase $(4,9,10)$ are expressed in the adjacent cells in a specific manner (11). In addition to this remarkable functional specialization, the two

Received February 24, 1987; accepted June 3, 1987.

Correspondence Harry Holthöfer, M.D., Ph.D., Department of Bacteriology and Immunology, University of Helsinki, Haartmanink 3 SF-00290 Helsinki 29, Finland.

Supported by a Public Health Service International Fellowship (1-F05-TWO3744-01). main epithelial cell types show distinct morphologic features (1, 2,12 ). Further structural-functional specialization of intercalated cells into type A (acidifying) and B (alkalinizing) has been proposed recently on the basis of discoveries in the intracellular polarization of proton secretion in respect to the apex or base of these cells $(13,14)$. However, little is known of the ontogeny of principal and intercalated cells or of the emergence of cell typespecific functions of collecting ducts, although this knowledge would provide better understanding of the unique functional features of the maturing kidney.

Herein an immunocytochemical approach using highly specific antibodies against $(\mathrm{Na}+\mathrm{K})$-ATPase, CA II (isoenzyme II) and band 3 glycoprotein (the anion channel protein of erythrocytes) was taken to study the evolution of functional specialization of the cell types of rat kidney collecting ducts.

\section{MATERIALS AND METHODS}

Tissue samples. Three whole embryos of Sprague-Dawley rats at gestational age of 18 days, and kidney samples collected from three newborn rats at 2 and $12 \mathrm{~h}$ of age, and sequentially at 2,5 , $9,15,20$, and 30 days were used. The animals were sacrificed by decapitation after ether anesthesia and immediately after preparing the kidneys (or whole 18th day embryos cut along sagittal plane) the tissues were placed for $5 \mathrm{~h}$ in a fixative consisting of $6 \% \mathrm{HgCl}, 1 \%$ sodium acetate, and $0.1 \%$ glutaraldehyde which has been shown to provide good retention of the tissue antigenicities studied (11). After fixation, the tissues were routinely embedded in paraffin.

Antibodies. The antibodies against affinity purified CA II isoenzyme were raised in rabbits as described earlier in detail (15). The purity and specificity testing of these antibodies have been documented extensively $(4,16)$.

Rabbit anti-(Na+K)-ATPase antiserum used was a generous gift from Dr. G. Siegel (Department of Neurology, University of Michigan, Ann Arbor, MI) and was raised in rabbits against a mouse brain $(\mathrm{Na}+\mathrm{K})$-ATPase catalytic unit as described earlier in detail (8). A mouse brain microsomal membrane fraction enriched in $(\mathrm{Na}+\mathrm{K})$-ATPase was prepared according to procedures previously described (8), and from the active preparation thus obtained, the $(\mathrm{Na}+\mathrm{K})$-ATPase catalytic unit was purified using SDS-PAGE with $8.75 \%$ separating gel. The eluted catalytic unit fraction was then used to immunize rabbits with complete Freund's adjuvant (8). Immunoblot analysis of specificity showed that the antibody obtained recognized only one $100 \mathrm{kD}$ band in purified preparations of lamb kidney and duck salt gland on $8.75 \%$ PAGE. Immunoreactivity of the antibody with various mouse tissues has been characterized earlier (8).

Band 3 glycoprotein antiserum raised in rabbits was a kind gift from Dr. G. Pasternack (Department of Pathology, Johns Hopkins University, Baltimore, MD). The antigen was purified from human erythrocytes after extraction of spectrin, ankyrin, and protein 4.1 using previously described methods (17-19). The cytoplasmic domain of band 3 was further purified from high- 
salt extracted vesicles, and material thus obtained is referred to as $43 \mathrm{~K}$ peptides. Anti $43 \mathrm{~K}$ antibodies were obtained by immunizing rabbits, and were further affinity purified using a $43 \mathrm{~K}$ Sepharose column (20).

Staining procedure. An immunocytochemical staining procedure identical to that previously reported (11) was used. Briefly, $2-3 \mu \mathrm{m}$ tissue sections were treated with normal rabbit serum to block nonspecific staining, followed by incubation with a primary antiserum, either anti CA II at 1:1000, antiband 3 at $25 \mu \mathrm{g} / \mathrm{ml}$, or a 1:200 dilution of anti-( $\mathrm{Na}+\mathrm{K})$-ATPase for $1 \mathrm{~h}$ at room temperature. After a thorough rinse, the bound antiserum was
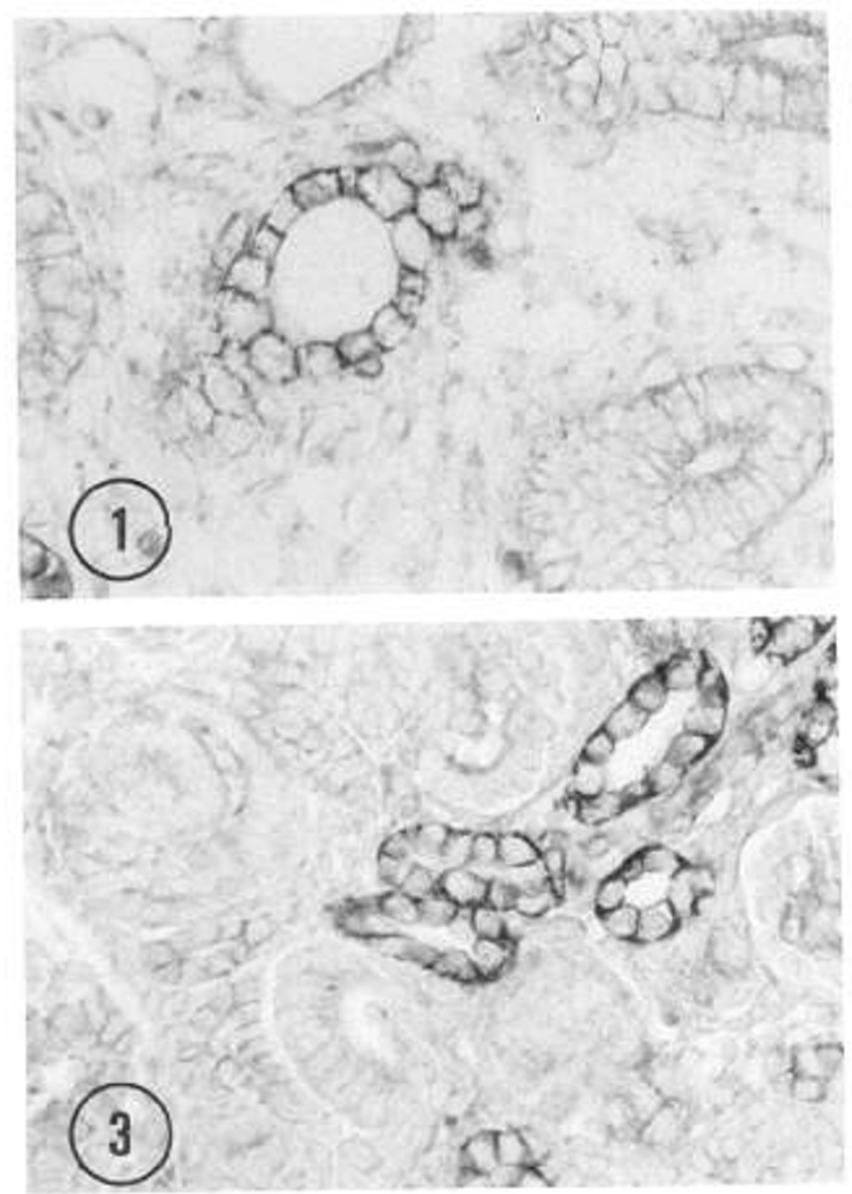

visualized using a rabbit Vectastain peroxidase $A B C$ kit (Vector Laboratories, Burlingame, $\mathrm{CA}$ ), including sequential exposure to biotinylated antirabbit immunoglobin and $A B C$ complex. Sites of bound antisera were visualized by incubation in DAB substrate solution.

Immunocytochemical controls included omission of either the primary or secondary antiserum from the staining sequence, as well as substitution of the primary antiserum with nonimmune rabbit serum. These control stainings resulted in no specific tissue reactivity. However, these control sections also served as the basis to evaluate the amount of unspecific background staining. Thus,

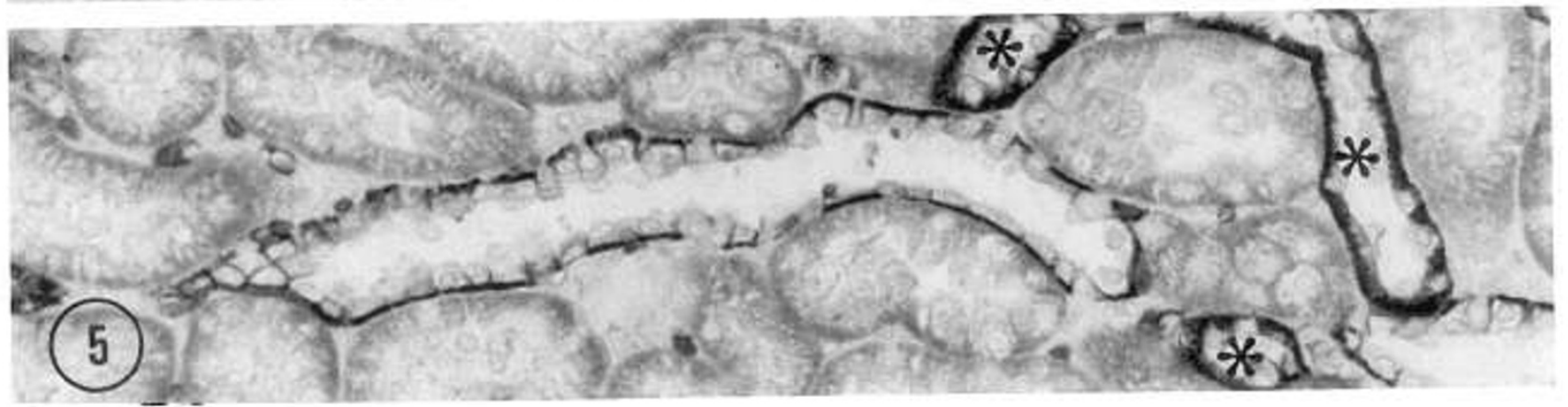

Fig. 1. Paraffin section of fetal rat kidney of 17 th gestational day, immunostaining for $(\mathrm{Na}+\mathrm{K})$-ATPase. Most collecting duct cells are positive. Note $(\mathrm{Na}+\mathrm{K})$-ATPase immunoreactivity also in the apical aspect of cells. Original magnification $\times 150$.

Fig. 2. In 12-h postnatal rat kidneys $(\mathrm{Na}+\mathrm{K})$-ATPase immunoreactivity is seen mainly at the basal but also in the lateral membranes of collecting duct cells. Original magnification $\times 260$.

Fig. 3. In 2-day-old rats ( $\mathrm{Na}+\mathrm{K})$-ATPase immunoreactivity shows considerable polarization to the basolateral aspect of collecting duct cells. Original magnification $\times 150$.
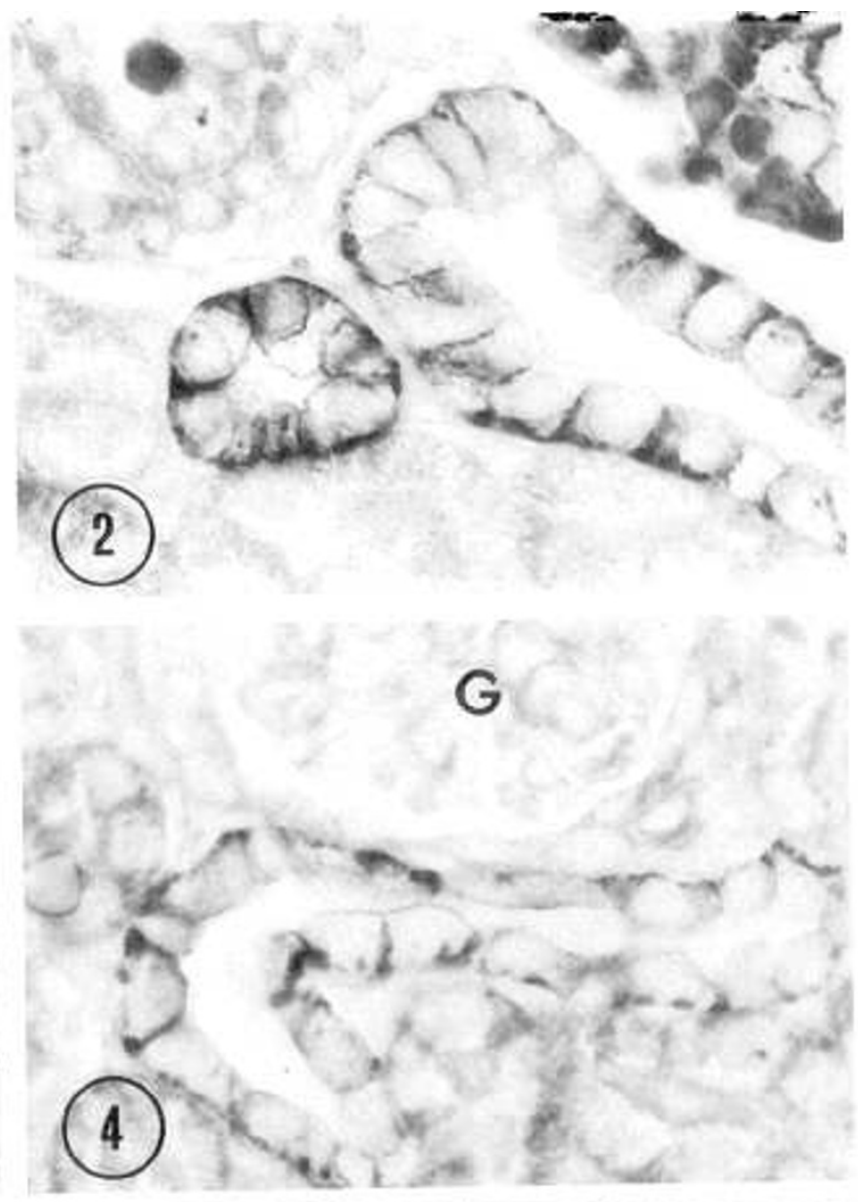

Fig. 4. (Na+K)-ATPase immunostaining of 7 th day postnatal rat kidney shows further polarization of the enzyme reactivity. Note also the presence of cells negative for this enzyme. $G$, glomerulus. Original magnification $\times 260$.

Fig. 5. In 30-day postnatal rat kidney $(\mathrm{Na}+\mathrm{K})$-ATPase immunostaining reveals an adult type of reactivity of cortical collecting duct cells in respect to the intracellular polarization and amount of immunoreactive cells. Asterisks, profiles of the loops of Henle. Original magnification $\times 150$. 
when present, specific tissue reactivity could be judged on a subjective basis as positive or negative for each cell, by comparing the specific tissue reactivity to the background staining given by the control sections.

\section{RESULTS}

Both the embryonic and postnatal rat kidneys showed good morphologic preservation and presence of a cortical zone of continuing nephrogenesis which could be identified up to 15 th day of age. All the antibodies used gave a characteristic mosaiclike staining of the collecting duct cell populations $(4,11)$, and all the samples of similar ages gave closely similar amounts of cells that were positive. In the 30th-day samples, the staining pattern with each antibodies resembled that seen in the adult rat kidney, in respect to the amount of cells positive, subcellular polarization of the antigenicity, and morphologic cell types positive for these antibodies (11).

Appearance of $(\mathrm{Na}+\mathrm{K})$-ATPase immunoreactivity. $(\mathrm{Na}+\mathrm{K})-$ ATPase immunoreactivity was seen in the collecting duct cells already in fetal rat kidneys at the 17 th gestational day (Fig. 1). At this stage most collecting duct profiles, identified by morphology, showed $(\mathrm{Na}+\mathrm{K})$-ATPase immunoreactivity, although considerable variation in the staining intensity of different collecting duct profiles was observed. Most lining cells of collecting ducts appeared immunoreactive for this antibody, but notably no intracellular polarization could be observed at this stage. Thus, the lateral membranes and base of the cells, as well as the apical cellular aspect were positive for the $(\mathrm{Na}+\mathrm{K})$-ATPase anti-
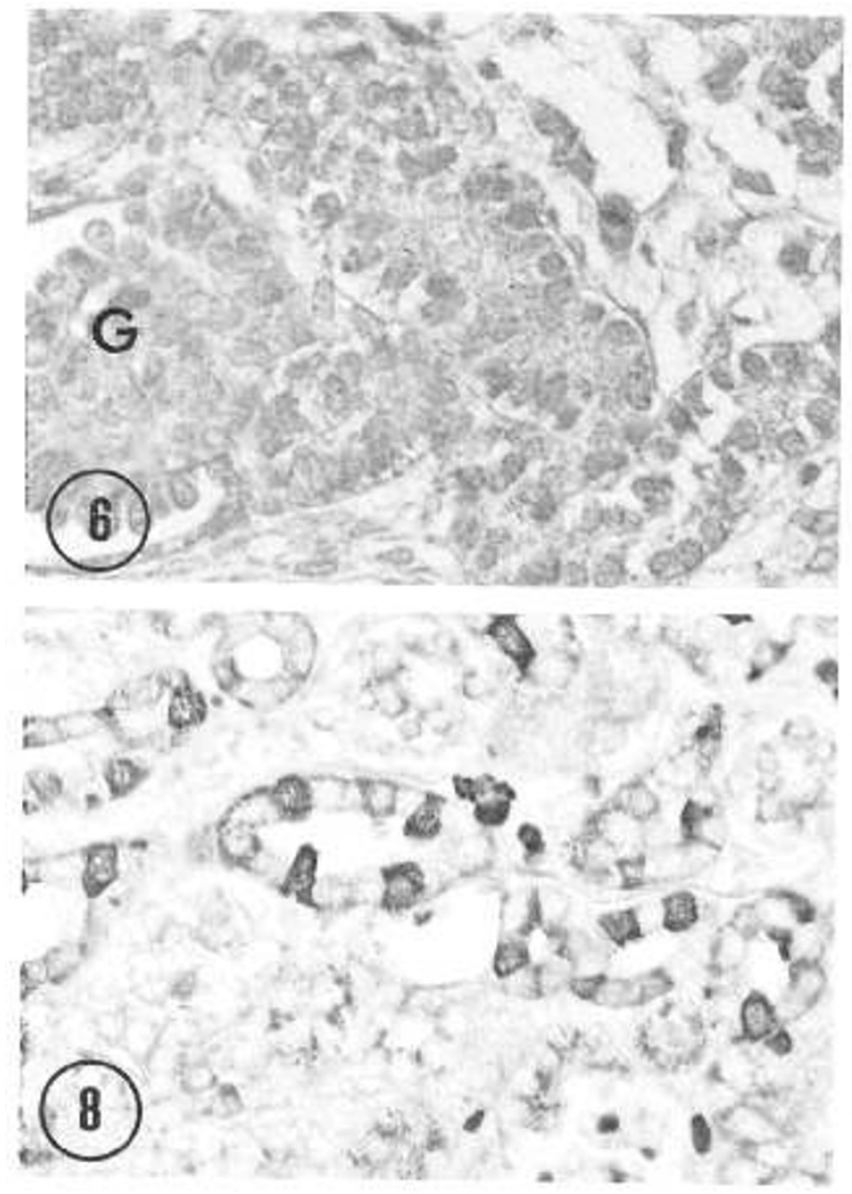

Fig. 6. Seventeenth-day embryonic rat kidney immunostaining for CA II. No positive cells can be seen. $G$, glomerulus. Original magnification $\times 260$.

Fig. 7. In 2-h postnatal kidneys, only occasional collecting duct cells appear immunoreactive for CA II. Original magnification $\times 260$. bodies. In 2-h postnatal kidneys a closely similar pattern of $(\mathrm{Na}+\mathrm{K})$-ATPase expression was seen. In 12-h postnatal samples (Fig. 2), first signs of intracellular polarization appeared as immunoreactive $(\mathrm{Na}+\mathrm{K})$-ATPase was found preferentially at the base of the cells, although considerable immunoreactivity still also persisted at the lateral membranes. On the other hand, only faint to hardly detectable immunoreactivity was seen at the apical cellular aspect. With increasing age (Figs. 3 and 4) the amount of $(\mathrm{Na}+\mathrm{K})$-ATPase positive cells in collecting ducts seemed to decrease in relation to the evolving population of cells positive for CA II. The typical amount of (Na+K)-ATPase immunoreactive cells as found in the adult rat kidney (11) was achieved by the 30th postnatal day (Fig. 5).

Appearance of CA II immunoreactivity. Immunoreactive CA II could not be detected in the fetal rat kidney samples studied (Fig. 6). In the 2-h postnatal kidneys, only occasional CA II immunoreactive cells were seen in collecting ducts (Fig. 7). However, in the 12-h kidney samples the amount of cells rich in carbonic anhydrase increased considerably. After this, a steady increase in the amount of cells immunoreactive for CA II (Fig. 8) could be seen concomitantly with an increase in the intensity of immunoreaction. An adult type of CA II expression in respect to the typical amount of cells positive in each collecting duct segment was reached between 20- and 30-day kidney samples (Fig. 9). No particular pattern of intracellular polarization of CA II immunoreactivity could be observed.

Appearance of band 3 immunoreactivity. No band 3 immunoreactivity could be seen during early postnatal period (Fig. 10), and not until day 5 a few collecting duct cells expressing band 3
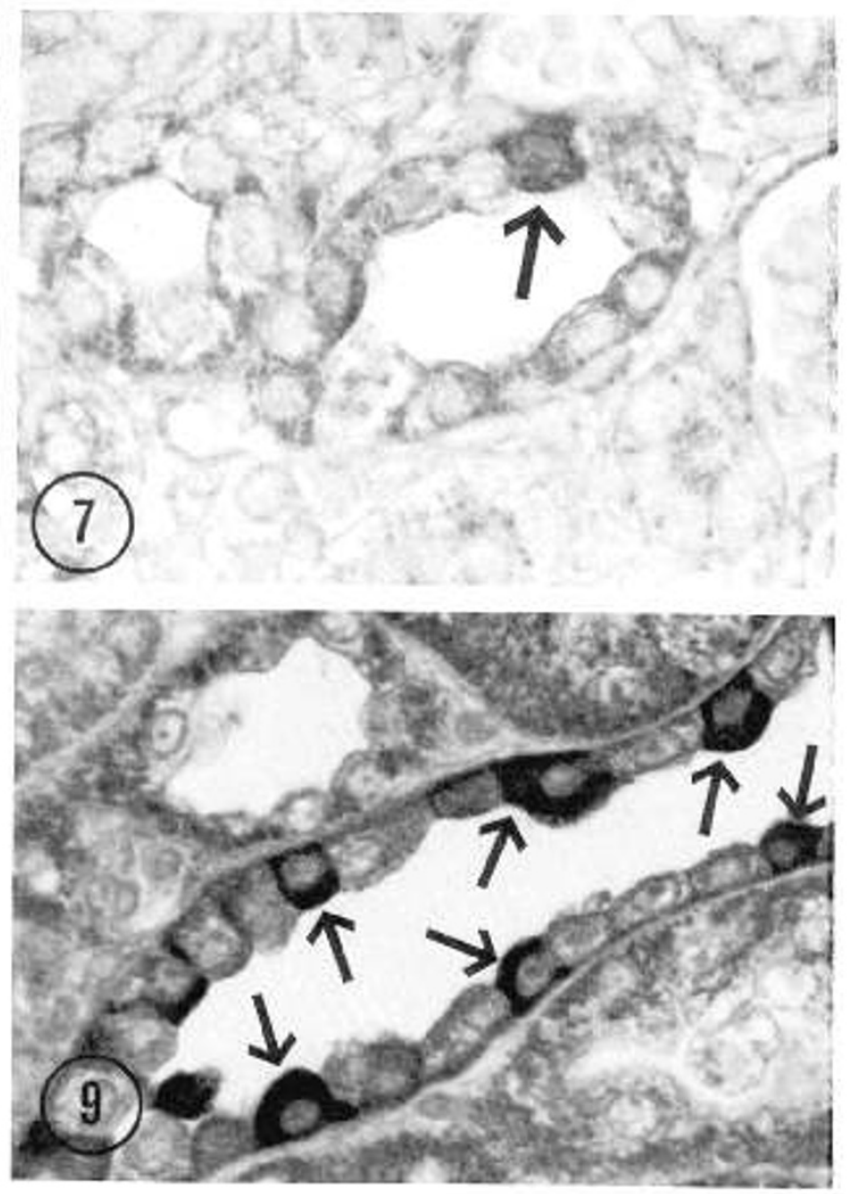

Fig. 8. In 7th-postnatal day rat kidneys several CA II-rich cells can be seen along collecting ducts. Original magnification $\times 150$.

Fig. 9. An adult type of CA II immunoreactivity can be seen in cortical collecting duct cells (arrows) of 30th-day rat kidneys. Original magnification $\times 260$. 
immunoreactivity at the basolateral aspect were seen to appear. After this timepoint, a steady increase in the amount of band 3 positive cells could be observed (Fig. 11). However, as late as day 15 the amount of band 3 positive cells was still relatively low, and did not achieve the amount found in adult rat kidney collecting ducts until at day 30 (Fig. 12). The evolution of cell types with the various immunoreactivities studied is illustrated in Figure 13.

\section{DISCUSSION}

Considerable morphologic maturation and increase in the amount of nephrons takes place during the first weeks of life in rats (21). Thus, mature nephrons can be found deep in the cortex, whereas the zone of continuing nephrogenesis is located beneath the renal capsule. Although morphologic maturation of glomerular and tubular elements has been extensively studied (22-24), the evolution of the functional and structural complexity, especially at the collecting duct, which is the site of final control of urinary acidification and electrolyte composition (1, 5 ), is still poorly understood. Thus, the mechanisms explaining the unique functional features of neonatal kidneys, and for example the transient metabolic acidosis, a phenomenon typical for both full term but especially premature infants $(25,26)$, remain to be characterized further. The recently introduced immuno- and enzymecytochemical methods detecting key transport enzymes $(8,11,27)$ have shown to be useful for providing valuable information on the nephron site and cell type specific location of the transport processes, giving thus new insight into the respective functions. However, a main limitation of those techniques is that they offer only limited possibilities for quantitative analysis of the tissue and cell reactivities.

The present findings show that $(\mathrm{Na}+\mathrm{K})$-ATPase, the enzyme characteristic for principal cells (7), is present early in utero in most collecting duct cells. It is also noteworthy that during early postnatal development the amount of $(\mathrm{Na}+\mathrm{K})$-ATPase-positive cells steadily decreased, seemingly in parallel with the increase of cells rich in carbonic anhydrase. This may suggest that the cells responsible for maintaining acid-base balance are recruited from the pool of the morphologically more uniform principal cells, as also suggested earlier (28). Interestingly, the rapid change in the intracellular polarization of $(\mathrm{Na}+\mathrm{K})$-ATPase in principal cells and the appearance of detectable cells with abundant carbonic anhydrase coincided within $12 \mathrm{~h}$ after birth, perhaps an indication of functional activation in these cells.

Lonnerholm and Wistrand (29) showed carbonic anhydrase activity in kidneys during early phases of intrauterine life, whereas herein this enzyme was not immunocytochemically detectable in fetal kidneys. However, Lonnerholm and Wistrand (29) used an enzyme histochemical technique which is not specific for the isozyme found preferentially in kidneys (10), and more important, they studied human fetal kidneys. The wellrecognized species differences in both the structure and function of collecting ducts (1) may thus explain this controversy. In addition, it has been reported that dark (intercalated) cells as well as their characteristic enzymes are not present in newborn rat or mouse kidneys $(21,30)$. Whether a fetal type of CA II with different antigenic characteristics and thus undetectable for the antibodies used is present remains to be explored.

Recent results have shown that two types of CA II-rich (intercalated) cells can be identified in rat kidney collecting ducts, based on the simultaneous presence or absence of basolateral band 3 glycoprotein (11). This glycoprotein is involved in the basolateral exchange of intracellular bicarbonate for serosal chloride (17). For counterbalancing, protons are secreted at the apical cellular aspect and these cells would thus be the acidifying type of intercalated cells as proposed by Schuster et al. (31). Also, the intercalated cells lacking basolateral band 3 are likely to be of the other identified intercalated cell subpopulation responsible for bicarbonate secretion. This is in line with the acidification model as proposed by Stone et al. (6), and is further supported by the findings of Schwartz et al. (13) who identified two types of intercalated cells with differing acid secretion characteristics and with reversed intracellular polarization of vacuoles important in proton secretion. Interestingly, in this study band 3 reactivity was not found until day 5 of postnatal life, with only slowly increasing staining intensity and, more important, slowly increasing amount of cells positive for this antibody. This indicates that the intercalated cells with acid secreting capacity evolve slowly during the first weeks of life. This is in agreement with
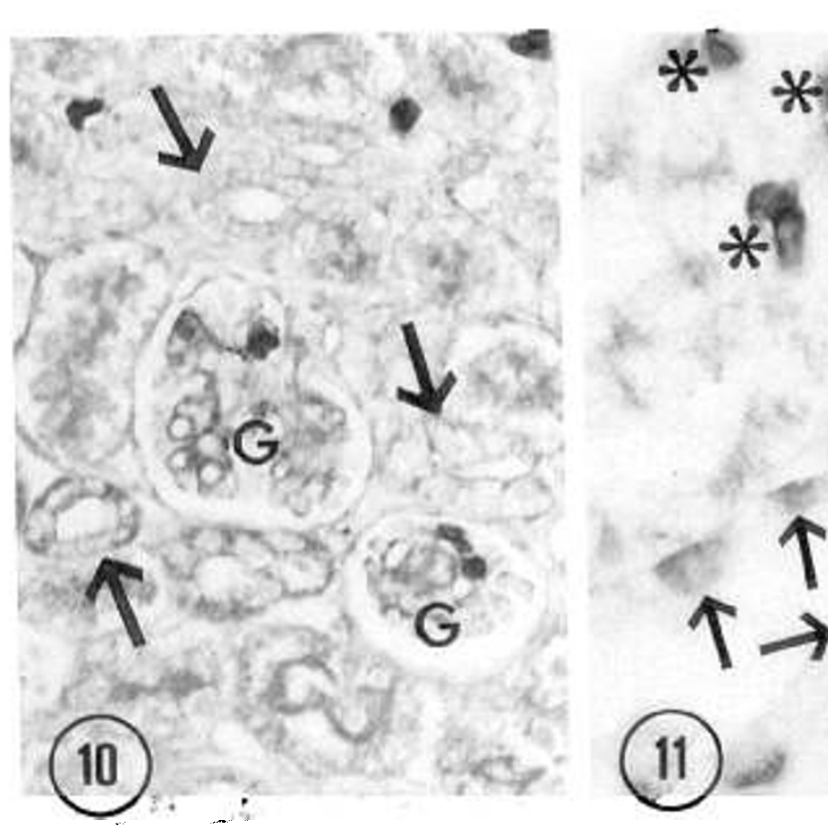

Fig. 10. Paraffin section of kidney of a 2-day-old rat, immunostaining for band 3 glycoprotein. No reactivity at the collecting ducts (arrows) can be seen. $G$, glomerulus. Original magnification $\times 150$.

Fig. 11. In the kidneys of 20-day-old rat several cells of cortical collecting ducts show immunoreactivity for band 3 (arrows) at the base

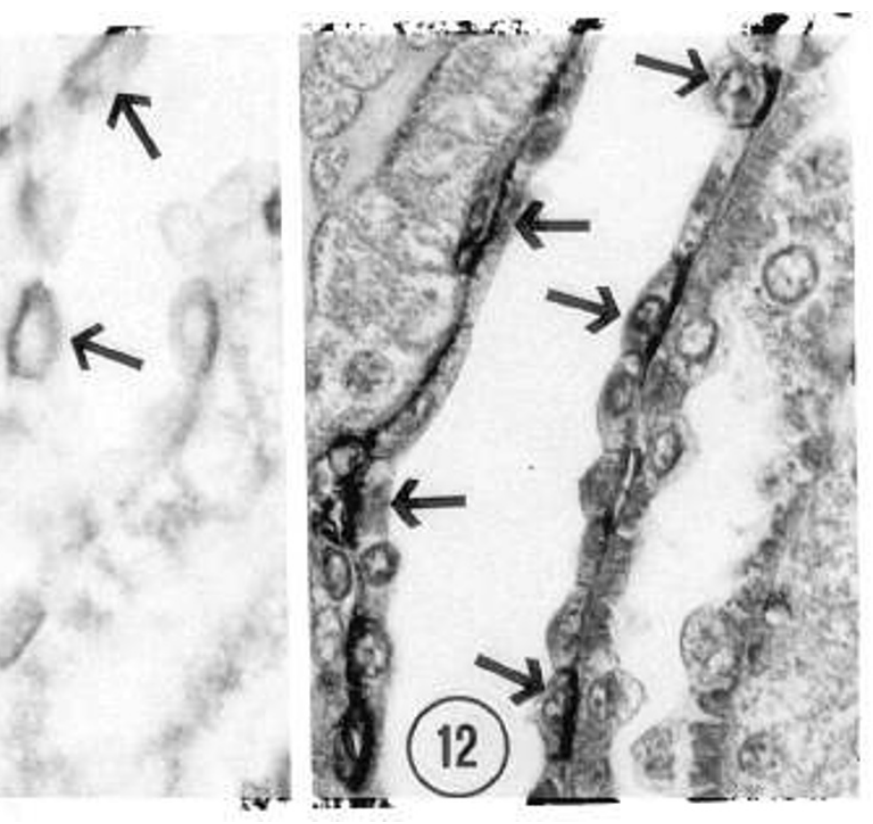

of the cells. Asterisks denote erythrocytes positive for this antibody. Original magnification $\times 260$.

Fig. 12. In 30-day rat kidney, a typical basolateral polarization of band 3 immunoreactivity is seen in a subpopulation of cortical collecting duct cells. Original magnification $\times 260$. 


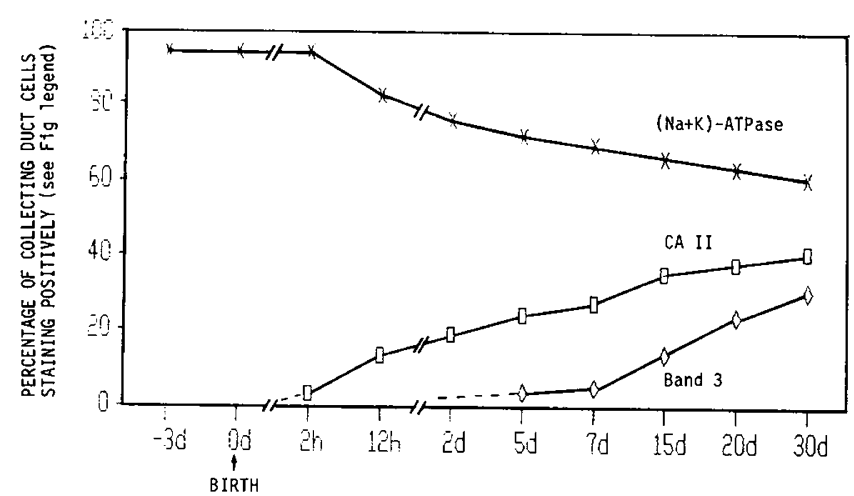

Fig. 13. Amount of collecting duct cells at each timepoint showing positive immunostaining for $(\mathrm{Na}+\mathrm{K})$-ATPase, CA II, and band 3 glycoprotein in fetal ( -3 to 0 days) and postnatal ( $2 \mathrm{~h}$ to 30 days) rat kidneys. The amounts given are percentages of total collecting duct cells and are obtained by calculations from five to eight collecting duct profiles from three samples at each timepoint.

previous studies showing that the limitation of collecting ducts to create $\mathrm{H}^{+}$gradient disappears within approximately $2 \mathrm{wk}$ of age (32). However, a contributory effect of functionally immature bicarbonate resorption capacity, as shown for the cells of proximal tubules of newborn rabbits (33), cannot be excluded on the basis of the present findings.

The present results show that the immunocytochemically detectable vital enzyme reactivities of collecting duct cell types appear in a sequential manner, reflecting most likely a similar order of functional activation of the respective cell types. Although the current approach cannot provide information of the functional activity or quantitation of the enzymes, these results extend the understanding of the early maturation of the collecting duct cell types and offer also a plausible explanation for the unique functional features of neonatal kidneys. Important areas of further inquiry include the study of signals triggering the rapid expression of the transport enzymes and molecular mechanisms leading to their polarized expression.

Acknowledgement. The author thanks Dr. B. A. Schulte (Medical University of South Carolina, Charleston, SC) for placing the excellent facilities of the histochemical laboratory at his disposal.

\section{REFERENCES}

1. Kriz W, Kaissling B 1985 Structural organization of the mammalian kidney. In: Seldin DW, Giebish G (eds) The Kidney. Physiology and pathophysiology. Raven Press, New York, pp 265-306

2. Madsen K, Tisher CC 1986 Structural-functional relationships along the distal nephron. Am J Phys 250:F1-FI5

3. Stanton B, Janzen A, Klein-Robbenhaas G, DeFrengo R, Giebish G, Wade J 1985 Ultrastructure of rat initial collecting tubule. Effect of adrenal corticosteroid treatment. J Clin Invest 75:1327-1334

4. Sato A, Spicer SS 1982 Cell specialization in collecting tubules of the guinea pig kidney: carbonic anhydrase activity and glycosaminoglycan production in different cells. Anat Rec 202:431-443

5. Steinmetz P 1986 Cellular organization of urinary acidification. Am J Physiol 249:F173-F187

6. Stone DK, Seldin DW, Kokko JP, Jacobson HR 1983 Anion dependence of rabbit medillary collecting duct acidification. $\mathbf{J}$ Clin Invest 71:1505-1508

7. Ernst S, Schreiber JH 1981 Ultrastructural localization of $\mathrm{Na} / \mathrm{KATPase}$ in rat and rabbit kidney medulla. J Cell Biol 91:803-813

8. Siegel GJ, Holm C, Schreiber JH, Desmond T, Ernst SA 1984 Purification of mouse brain ( $\mathrm{Na}+\mathrm{K})$-ATPase catalytic unit, characterization of antiserum, and immunocytochemical localization in cerebellum, choroid plexus and kidney. J Histochem Cytochem 32:1309-1318

9. Lonnerholm G, Ridderstrahle Y 1980 Intracellular distribution of carbonic anhydrase in the rat kidney. Kidney Int 17:162-174

10. Dobyan DC, Bulger RE 1982 Renal carbonic anhydrase. Am J Physiol 243:F311-F324

11. Holthöfer H, Schulte BA, Pasternack G, Siegel G, Spicer SS Three functionally distinct cell populations in the rat kidney collecting duct. Am J Physiol (in press)

12. Tisher CC, Madsen KM 1986 Anatomy of the kidney. In: BM Brenner, FC Rector Jr (eds) WB Saunders Co, Philadelphia, pp 1-60

13. Schwartz GJ, Barasch J, Al-Awqati Q 1985 Plasticity of functional epithelial polarity. Nature 318:368-371

14. Stetson D, Steinmetz PR 1985 a and b types of carbonic anhydrase rich cells in turtle bladder. Am J Physiol 249:F553-F565

15. Osborne WRA, Tashian RE 1973 An improved method for purification of carbonic anhydrase enzymes by affinity chromatography. Anal Biochem 64:297-313

16. Spicer SS, Stoward PJ, Tashian RE 1979 The immunohistolocalization of carbonic anhydrase in rodent tissues. J Histochem Cytochem 27:820-831

17. Knauf PA 1977 Erythrocyte anion exchange and the band 3 protein transport kinetics and molecular structure. Curr Top Membr Transp 12:249-363

18. Leto TL, Marchesi VT 1984 A structural model of human erythrocyte 4.1. J Biol Chem 259:4603-4608

19. Pasternack GR, Anderson RA, Leto TL, Marchesi VT 1983 Interaction between protein 4.1 and band 3. An alternative binding site for an element of the membrane skeleton. J Biol Chem 260:3676-3683

20. Hazen-Martin DJ, Pasternack G, Spicer SS, Sens DA 1986 Immunolocalization of band 3 in normal and cystic fibrosis skin. J Histochem Cytochem 34:823826

21. Clark SL 1957 Cellular differentiation in the kidneys of newborn mice studied with the electron microscope. J Biochem Biophys Cytol 3:349-362

22. Kazimierczak J 1971 Development of renal corpuscle and the juxtaglomerular apparatus. A light and electron microscopic study. Acta Pathol Microbiol Scand [A] 218:1-64

23. Larsson $L 1975$ The ultrastructure of the developing proximal tubule in the rat kidney. J Ultrastruct Res 51:119-129

24. Potter E 1965 Development of the human glomerulus. Acta Pathol 80:241255

25. Edelmann CM Jr, Rodriquez-Soriano J, Boichis H, Gruskin AB, Acosta M 1962 Renal bicarbonate reabsorption and hydrogen ion secretion in neonatal infants. $J$ Clin Invest 46:1309-1317

26. Graham Bd, Wilson JL, Makepeace UT, Baumann ML, Brown S 1951 Development of neonatal electrolyte homeostasis. Pediatrics 8:68-78

27. Kashgarian M 1984 Use of monoclonal antibodies in the study of renal function. Am J Physiol 247:F533-F538

28. Ordonez NG, Spargo BH 1974 The morphologic relationship of light and dark cells of the collecting tubules in potassium depleted rats. Am J Pathol 84:317326

29. Lonnerholm G, Wistrand PJ 1983 Carbonic anhydrase in the human fetal kidney. Pediatr Res 17:390-397

30. Brown D, Kumpulainen T, Roth J, Orci L 1983 Immunohistochemical localization of carbonic anhydrase in postnatal and adult rat kidney. Am J Physiol
245:F110-F1 18

31. Schuster VL, Bonsib SM, Jennings ML 1986 Two types of collecting duct mitochondria-rich (intercalated) cells: lectin and band 3 cytochemistry. Am J Physiol 251:C347-C355

32. Monnens L, Shretten G, van Munter J 1973 The renal excretion of hydrogen ions in infants and children. Nephron 12:29-43

33. Schwartz GJ, Evan AP 1983 Development of solute transport in rabbit proximal tubule. $\mathrm{HCO}_{3}$ and glucose absorption. Am J Physiol F382-F390 